\title{
EFFECT OF SEASON ON SOME THERMOREGULATION AND BLOOD PICTURE IN DAMASCUS AND ZARABI MALE GOATS
}

\author{
H. Abdel Rahman, Reem S. Mourad, Mervat M. Soliman and A. F. Nebar \\ Animal Production Department, Faculty of Agriculture, Menofiya University
}

Received: Sep. 25,2019

Accepted: Sep. 29, 2019

\begin{abstract}
The effect of seasonal variations on some thermoregulation and blood parameters were studied in ten male goats (five Zarabi and five Damascus). Rectal temperature, pulse rate and respiration rates were determined at 7:00, 12;00 and 19:00 during the middle month of every season. Blood samples were collected and was shortly analyzed after collection for RBCs, WBCs, $\mathrm{Hb}$ and PCV. Mean corpuscular volume (MCV), $(\mathrm{MCH})$, and $(\mathrm{MCHC})$ were mathematically calculated. Data were statistically analyzed using SAS (2007). Results indicated that season of the year affected significantly thermoregulation parameters and RBCS indices which were estimated in males of Damascene and Zraibi goats. the highest overall averages of $R T, R R$ and $P R$ were recorded in summer season $\left(39.06^{\circ} \mathrm{C}, 38.4 \mathrm{acts} / \mathrm{min}\right.$ and $\left.87.8 \mathrm{beat} / \mathrm{min}\right)$ for the males goats of Damascus and Zarabi and were accompanied by the highest recorded ambient temperature and THI during that season. The highest RBC, Hb, PCV and MCHC values $(11.8 \times 106 / 11.81,9.4 \mathrm{~g} / \mathrm{dL}, 30.9 \%$ and $31.7 \mathrm{~g} / \mathrm{dL})$ were recorded in winter, and the highest values of $\mathrm{MCV}$ and $\mathrm{MCH}$ ( $30.4 \mathrm{fl}, 9.0 \mathrm{pg}$ ) in summer, however, The highest (11.4 $(\times 103 / \mu L)$ and lowest $(9.1 \times 103 / \mu L)$ overall average of the total WBC were recorded in spring and winter, respectively in Damascus and Zraibi male blood samples. It could be concluded that season of the year affected significantly hematological and thermoregulation parameters estimated in males of Damascene and Zraibi goats in the present study, however, the values of all parameter were mostly within the physiological range for goats as reported from previous studies.
\end{abstract}

Key words: Season, goats, thermoregulation, blood picture.

\section{INTRODUCTION}

Goats are multipurpose animals; they produce. milk, meat, skin and fiber, and play a predominant role in the sustenance of the livelihoods of impoverished families especially in the rural areas. Goats contribute a great deal to the agriculture economy of Egypt, where goats contribute about $5 \%$ of all the red meat (Galal et al. 2005), and less than $1 \%$ of the total milk production in Egypt (Soryal \& Metawi 2000).

Recent climate change happens in Egypt as in all over the world as a result of global warming that causes a lot of failure in animal performance. In this concern, (Sherien and Yassien 2016) stated that analysis of meteorological data of Egypt climate showed a marked climate change starting the year 2011, explained by an increase in both air temperature and Temperature-Humidity Index (THI), and this change was negatively correlated with total day milk yield of Holstein cows maintained in the Egyptian Delta region. Moreover, obtained results of her study expected the continuous negative effect of climate change till the year 2050. Heat stress has been generally associated with detrimental effects on physiological equilibriums of goats and their various systems (nervous, endocrine and immune) have been implicated with specific responses and reciprocal 
regulatory influences (Castanheira et al., 2010).

So, the present study was conducted to investigate the seasonal variations of some thermoregulation parameters (Rectal temperature, Respiration rate and Pulse rate) and some Blood constituents in male Damascus and Zarabi goats.

\section{MATERIALS AND METHODS}

Five Zarabi and five Damascus male goats aged from 1.5 - 2.0 years were randomly selected from the goat flock of search farm of the Animal production Department, Faculty of Agriculture Menofiya University (Shebin El- Kom). The animals were healthy, kept under similar managerial conditions. and housed in 2 separate semi-open pens. The experiment started at December 2016, and lasted for a year. The animals were fed in groups, and were provided with their nutritional requirement according to the feeding system applied in this farm. This included concentrate plus wheat straw plus berseem hay (Trifolium alexandrium) during season of the green fodder, the feed allowance was according to NRC (2007). Rations were offered to all animals twice a day of 08:00 a.m. and 3.00 p.m., The feeding allowance were adjust monthly according to changes in body weight. Fresh water was available ad lib. for the animals all over the period of the experiment.

Ambient temperature $\left(A T,{ }^{\circ} \mathrm{C}\right)$, relative humidity $(\mathrm{RH} \%)$ were measured at the experimental region at 7:00, 12:00 and 19: $00 \mathrm{hrs}$ and recorded to measure the micro-environment surround the animals. Then, Temperature Humidity Index (THI) was calculated according to the equation of Nigm et al., (2015) as:

$\mathrm{THI}=32.783+1.478 \times \mathrm{AT}+0.056 \times \mathrm{RH}$

Where:

32.783 is the intercept, 1.478 is the regression of THI on AT, 0.056 is the regression of THI on $\mathrm{RH}$, AT is the average of air temperature $\left({ }^{\circ} \mathrm{C}\right)$ and $\mathrm{RH}$ is the average of relative humidity (\%). The accuracy of this equation $\left(R^{2}\right)$ is $\mathbf{0 . 9 9 5}$.

\section{Measurements and observations:}

1- Thermoregulation responses:

To investigate the effect of season on the physiological responses of the experimental goats, rectal temperature, pulse rate and respiration rates were determined three times /day (at 7:00a.m., 12:00. and 19:00 hrs) during the middle month of every season.

Rectal temperature was measured to the nearest $0.01^{\circ} \mathrm{C}$ using a standard clinical thermometer inserted into the rectum approximately $10 \mathrm{~cm}$ for 2 minutes, respiratory rate was determined by counting the number of abdominal movement per minute, and pulse rate was recorded by placing the finger tips on the femoral arteries of the hind limb for one minute and read from the stopwatch as reported by Sanusi et al. (2010).

\section{2- Blood picture:}

Blood samples were collected during the middle month of every season Blood samples were collected from the jugular vein of each animal at morning before feeding or drinking in a vial, the vial was heparinized with ethylene diamine tetra acetic acid (EDTA) as an anticoagulant.

ALL parameters of blood picture (Erythrocytes, RBCc, Leucocytes, WBCc, Hemoglobin concentration $(\mathrm{Hb})$ and Packed cell volume (PCV, \%), Mean corpuscular volume (MCV), mean corpuscular hemoglobin (MCH), and mean corpuscular hemoglobin concentration ( $\mathrm{MCHC}$ ) were mathematically calculated. Data were statistically analyzed using least squares procedure described by SAS (2007). Through this software, Duncan Multiple 
Range Test was applied to test the level of significant among the means.

\section{RESULT AND DISCUSSION}

I. Seasonal variation of thermoregulatory parameters in Damascus and Zaraibi goats:

Three thermoregulatory parameters were included in this study as rectal temperature (RT), respiration rate (RR) and pulse rate (PR). Data listed indicated that season (S), time of day (TD) and the interaction of (S X D) had significant ( $p<$ 0.01 ) effects on the three considered parameters (RT, RR and PR).

First able, Depending on the obtained result of recorded climatic elements (AT, $\mathrm{RH}, \mathrm{THI})$ during various seasons at the experimental region, it could be concluded that climatic condition in summer season characterized by the highest average of AT combined with the highest average of $\mathrm{RH}$, and accordingly with the highest THI level as compared with other seasons. Where, the highest overall average of $\mathrm{AT}^{\circ} \mathrm{C}, \mathrm{RH} \%$ and $\mathrm{THI}$ were recorded for summer season (29.1, 68.0 and 79.5) as compared with that of Winter (14.3, 61.4, 57.3), Spring ( 26.0, 42.3, 66.0) or in Autumn (21.5, 66.1 and 68.1, respectively). And across hours of the day the highest values of considered climatic parameters were recorded at 12.00 for AT and THI (27.5 and 75.6 respectively), However the highest values of $\mathrm{RH}$ recorded at $7.00 \mathrm{hrs}$ (79.6\%).

\section{a) Rectal temperature (RT):}

Irrespective of season of the year, time of the day or other factors could affect RT of the experimental goats, rectal temperature of Damascus and Zarabi male goats in the present study ranged from $38.25^{\circ} \mathrm{C}$ to $39.42^{\circ} \mathrm{C}$ (Table, 1). These results are consistent with those obtained by Marai et al., 2007 who stated that rectal temperatures in goats varies from 38.3 and $39.9 \circ C$, and appear somewhat similar to that of Fasoro BF.1999) who found rectal temperature of goats ranged between $39.2^{\circ} \mathrm{C}$ and $39.8^{\circ} \mathrm{C}$. However, (Smith and Sherman 2009) observed that normal temperature $\left({ }^{\circ} \mathrm{C}\right)$ of goats ranged from 38.6 to $40.0 \circ \mathrm{C}$.

It clears that, the highest $(p<0.01)$ overall average of $\mathrm{RT}$ was recorded in summer season for males $\left(39.06{ }^{\circ} \mathrm{C}\right)$ of Damascus and Zarabi goats. However, the lowest ones recorded in winter season $\left(38.43^{\circ} \mathrm{C}\right)$.

Furthermore, Data in Table (1) indicate that the average of RT in spring season for males $\left(38.67{ }^{\circ} \mathrm{C}\right)$ was significantly lower than that recorded in summer season (39.06) and it was higher $(P<$ 0.001 ) as compared to that recorded in winter season (38.4). The overall average of RT in autumn was significantly lower (38.46) as compared with that recorded in spring (38.67) and summer (39.06), and it was insignificantly higher than that recorded in winter $(38,43)$ goats (Table, 1).

Our results agree with the results of Marai et al. (2007) who reported that the rectal temperature was lower in the winter than in the summer, and contradicts with the results of Ceyhan et al. (2006) who found that the rectal temperature was higher in the winter and in the first months of the spring than in the summer months .

Across hours of the day, obtained results (Table, 1$)$ proved that as the AT increased, RT of the experimental goats increased. the lowest overall average of $R T$ was significantly $(P<0.001)$ recorded in morning hours at 7:00 hrs in males $\left(38.4^{\circ} \mathrm{C}\right)$ of the Damascus and Zarabi goats, and as expected the highest ones recorded at 12:00 $\mathrm{hrs}\left(38.8{ }^{\circ} \mathrm{C}\right)$. The overall average of RT at afternoon hours (19:00 hrs) was significantly higher 
$\left(38.67^{\circ} \mathrm{C}\right)$ than that recorded at 7:00 hrs $\left(38.4^{\circ} \mathrm{C}\right)$, and significantly lower than that recorded at $12: 00 \mathrm{hrs}\left(38.85^{\circ} \mathrm{C}\right)$.

These obtained results in the present study indicate that as the AT increased, RT of the experimental goats increased. In this regard, Marai, et al (2007) and Marai and Haeeb (2010) demonstrated that exposure of animals to high environmental temperature and relative humidity with prolonged direct sunlight induce heat-stress, which is known to adversely affect animal production. This high ambient temperature induces the animals to try to balance the excessive heat load by using different means to dissipate, as much as possible, their latent heat. If all such means fail, the body rectal temperature rises (Marai and Haeeb 2010).

\section{b) Respiration Rate (RR):}

The effect of season on RR of males of Damascus and Zarabi goats was significant $(p<0.01)$. Similar conclusion was reported by Kayabasi (2011). At first, frequency of respiration (RR) of males Damascus and Zarabi goats in the present study ranged from 24.8 to 45.0 acts/minute (Table, 2).

Table (1): Seasonal and diurnal changes of Rectal temperature ${ }^{\circ}(\mathrm{RT})$ :of Damascus and Zarabi male goats.

\begin{tabular}{|c|c|c|c|c|}
\hline \multirow{2}{*}{ Season (S) } & \multirow{2}{*}{ Time of day (D) } & \multicolumn{2}{|c|}{ Breed (B) } & \multirow{2}{*}{ Overall $(S \times D)$} \\
\hline & & Damascus & Zarabi & \\
\hline Winter & $\begin{array}{l}07.00 \mathrm{~h} \\
12.00 \mathrm{~h} \\
19.00 \mathrm{~h}\end{array}$ & $\begin{array}{l}38.25 \pm 0.4 \\
38.58 \pm 0.4 \\
38.58 \pm 0.4\end{array}$ & $\begin{array}{l}38.25 \pm 0.4 \\
38.59 \pm 0.4 \\
38.33 \pm 0.4\end{array}$ & $\begin{array}{c}38.25 \pm 0.03^{G} \\
38.58 \pm 0.03^{D E} \\
38.46 \pm 0.03^{F}\end{array}$ \\
\hline \multirow[b]{2}{*}{ Spring } & Overall (S x B) & $38.47 \pm 0.02$ & $38.39 \pm 0.02$ & $38.43 \pm 0.01^{c}$ \\
\hline & $\begin{array}{l}07.00 \mathrm{~h} \\
12.00 \mathrm{~h} \\
19.00 \mathrm{~h}\end{array}$ & $\begin{array}{l}38.55 \pm 0.4 \\
38.76 \pm 0.4 \\
38.73 \pm 0.4\end{array}$ & $\begin{array}{l}38.52 \pm 0.4 \\
38.73 \pm 0.4 \\
38.73 \pm 0.4\end{array}$ & $\begin{array}{c}38.53 \pm 0.03^{\mathrm{FE}} \\
38.74 \pm 0.03^{\mathrm{C}} \\
38.73 \pm 0.03^{\mathrm{C}}\end{array}$ \\
\hline \multirow[b]{2}{*}{ Summer } & Overall (S x B) & $38.68 \pm 0.02$ & $38.66 \pm 0.02$ & $38.67 \pm 0.01^{B}$ \\
\hline & $\begin{array}{l}07.00 \mathrm{~h} \\
12.00 \mathrm{~h} \\
19.00 \mathrm{~h}\end{array}$ & $\begin{array}{l}38.70 \pm 0.4 \\
39.48 \pm 0.4 \\
38.99 \pm 0.4\end{array}$ & $\begin{array}{l}38.73 \pm 0.4 \\
39.42 \pm 0.4 \\
39.06 \pm 0.4\end{array}$ & $\begin{array}{l}38.71 \pm 0.03^{C} \\
39.45 \pm 0.03^{A} \\
39.02 \pm 0.03^{B}\end{array}$ \\
\hline \multirow[b]{2}{*}{ Autumn } & Overall (S x B) & $39.05 \pm 0.02$ & $39.07 \pm 0.02$ & $39.06 \pm 0.01^{A}$ \\
\hline & $\begin{array}{l}07.00 \mathrm{~h} \\
12.00 \mathrm{~h} \\
19.00 \mathrm{~h}\end{array}$ & $\begin{array}{l}38.27 \pm 0.4 \\
38.62 \pm 0.4 \\
38.46 \pm 0.4\end{array}$ & $\begin{array}{l}38.23 \pm 0.4 \\
38.67 \pm 0.4 \\
38.50 \pm 0.4\end{array}$ & $\begin{array}{c}38.25 \pm 0.03^{G} \\
38.64 \pm 0.03^{C D} \\
38.48 \pm 0.03^{F}\end{array}$ \\
\hline & Overall (S x B) & $38.45 \pm 0.02$ & $38.56 \pm 0.02$ & $38.46 \pm 0.01^{c}$ \\
\hline & Total & $38.7 \pm 0.01$ & $38.6 \pm 0.01$ & \\
\hline & $\begin{array}{r}\text { Overall (B x D) } \\
07.00 \mathrm{~h} \\
12.00 \mathrm{~h} \\
19.00 \mathrm{~h}\end{array}$ & $\begin{array}{l}38.44 \pm 0.02 \\
38.86 \pm 0.02 \\
38.69 \pm 0.02\end{array}$ & $\begin{array}{l}38.43 \pm 0.02 \\
38.85 \pm 0.02 \\
38.65 \pm 0.02\end{array}$ & $\begin{array}{c}38.4 \pm 0.01^{C} \\
38.85 \pm 0.01^{A} \\
38.67 \pm 0.01^{B}\end{array}$ \\
\hline
\end{tabular}

$A, B=$ Values in the same column or row within certain trait with different super scripts are significantly differed $(P<0.05)$. 
Table (2): Seasonal and diurnal changes of respiration rate (acts/min) of Damascus and Zarabi male goats

\begin{tabular}{|c|c|c|c|c|}
\hline \multirow{2}{*}{ Season (S) } & \multirow{2}{*}{ Time of day (D) } & \multicolumn{2}{|c|}{ Breed (B) } & \multirow{2}{*}{ Overall (S x D) } \\
\hline & & Damascus & Zarabi & \\
\hline Winter & $\begin{array}{l}07.00 \mathrm{~h} \\
12.00 \mathrm{~h} \\
19.00 \mathrm{~h}\end{array}$ & $\begin{array}{l}25.6 \pm 0.5 \\
30.5 \pm 0.5 \\
27.6 \pm 0.5\end{array}$ & $\begin{array}{l}24.7 \pm 0.5 \\
31.8 \pm 0.5 \\
25.4 \pm 0.5\end{array}$ & $\begin{array}{l}25.1 \pm 0.4^{\mathrm{IJ}} \\
31.1 \pm 0.4^{\mathrm{D}} \\
26.5 \pm 0.4^{\mathrm{IH}}\end{array}$ \\
\hline \multicolumn{2}{|c|}{ Overall (S x B) } & $27.8 \pm 0.3$ & $27.3 \pm 0.3$ & $27.6 \pm 0.23^{C}$ \\
\hline Spring & $\begin{array}{l}07.00 \mathrm{~h} \\
12.00 \mathrm{~h} \\
19.00 \mathrm{~h}\end{array}$ & $\begin{array}{l}25.0 \pm 0.5 \\
30.3 \pm 0.5 \\
29.4 \pm 0.5\end{array}$ & $\begin{array}{l}23.6 \pm 0.5 \\
29.9 \pm 0.5 \\
29.1 \pm 0.5\end{array}$ & $\begin{array}{c}24.3 \pm 0.4^{J} \\
30.1 \pm 0.4^{\mathrm{DE}} \\
29.2 \pm 0.4^{\mathrm{EF}}\end{array}$ \\
\hline \multicolumn{2}{|c|}{ Overall (S x B) } & $28.25 \pm 0.3$ & $27.51 \pm 0.3$ & $27.9 \pm 0.23^{C}$ \\
\hline Summer & $\begin{array}{c}07.00 \mathrm{~h} \\
12.00 \mathrm{~h} \\
19.00 \mathrm{~h}\end{array}$ & $\begin{array}{l}32.8 \pm 0.5 \\
44.2 \pm 0.5 \\
37.6 \pm 0.5\end{array}$ & $\begin{array}{l}32.6 \pm 0.5 \\
45.0 \pm 0.5 \\
38.1 \pm 0.5\end{array}$ & $\begin{array}{l}32.7 \pm 0.4^{C} \\
44.6 \pm 0.4^{A} \\
37.8 \pm 0.4^{B}\end{array}$ \\
\hline \multicolumn{2}{|c|}{ Overall (S x B) } & $38.2 \pm 0.3$ & $38.6 \pm 0.3$ & $38.4 \pm 0.23^{A}$ \\
\hline Autumn & $\begin{array}{l}07.00 \mathrm{~h} \\
12.00 \mathrm{~h} \\
19.00 \mathrm{~h}\end{array}$ & $\begin{array}{l}29.0 \pm 0.5 \\
34.1 \pm 0.5 \\
27.6 \pm 0.5\end{array}$ & $\begin{array}{l}27.6 \pm 0.5 \\
33.4 \pm 0.5 \\
27.7 \pm 0.5\end{array}$ & $\begin{array}{c}28.3 \pm 0.4^{\mathrm{GF}} \\
33.8 \pm 0.4^{\mathrm{C}} \\
27.6 \pm 0.4^{\mathrm{GH}}\end{array}$ \\
\hline \multicolumn{2}{|c|}{ Overall (S x B) } & $30.2 \pm 0.3$ & $29.6 \pm 0.3$ & $29.9 \pm 0.23^{B}$ \\
\hline \multicolumn{2}{|c|}{ Total } & $31.1 \pm 0.1$ & $30.7 \pm 0.1$ & \\
\hline & $\begin{array}{l}\frac{B \times D)}{h} \\
h h \\
h\end{array}$ & $\begin{array}{l}28.1 \pm 0.3 \\
34.8 \pm 0.3 \\
30.5 \pm 0.3\end{array}$ & $\begin{array}{l}27.1 \pm 0.3 \\
35.0 \pm 0.3 \\
30.0 \pm 0.3\end{array}$ & $\begin{array}{l}27.6 \pm 0.2^{C} \\
34.9 \pm 0.2^{A} \\
30.3 \pm 0.2^{B}\end{array}$ \\
\hline
\end{tabular}

A, B = Values in the same column or row within certain trait with different super scripts are significantly differed $(P<0.05)$.

The tabulated data postulated that the highest overall average of $R R$ was recorded in summer season $(p<0.01)$ for males (38.40 acts/min) of Damascus and Zarabi goats. However, the lowest overall average of RR was counted and recorded $(27.60 \mathrm{acts} / \mathrm{min})$ in winter. In addition, the frequency of respiration was insignificantly higher in spring season for males $(27.9$ acts $/ \mathrm{min})$ as compared to that recorded RR in winter $(27.6$ acts $/ \mathrm{min})$ and it was significantly $(P<0.01)$ lower than that recorded in summer. In general, thermal, nutritional, and walking stress significantly affect the body weight, the respiratory rate, the heart rate, the rectal temperature of the animal (Sejian et al., 2013). Moreover, Srikandakumar et al. (2003) found that the respiratory rate per minute increased in hot conditions in Omani sheep. Several studies in sheep stated that, during summer months, the respiration rate is higher than in winter (Abi-Saaband - Saleim, 1995., Fahmy (1994)., Marai et al. (1997c)., Marai et al., 2007 and Yorulmaz (2014). Similar observations were recorded also for goats (Kayabasi 2011). 
The results of RR measured for the experimental goats pointed out that, the respiratory rate generally increased in parallel with the rise in temperature or THI in the summer. Similar conclusion was recorded by Appleman,1958Prasetyo., 1984 who indicated that the body temperature and respiration rate of goats increase with rise in ambient temperature. In contrast, Bligh J. 1985 observed that a daily change in respiration rate per minute from the effect of environmental temperature may not be parallel with change in body temperature and pulsation number.

Regarding to the activity of RR across hours of the day. The highest $(P<0.01)$ overall average of RR was recorded at noon (12:00 hrs) for males (34.91 acts/min) and the least activity of $R R$ was recorded at 7:00 a.m (27.60 acts/min) of the of Damascus and Zarabi goats (Table, 2). And that overall average of $R R$ at 19: hours $(30.3 \mathrm{acts} / \mathrm{min})$ was significantly $(p<0.01)$ lower than that recorded at 12:00 hrs, and higher than that recorded 7: hours. These findings agree with the results of Shalaby (1985), Yousef (1985) and Marai et al. (1997c) who found that RR was markedly lower at 8:00 am than at 12:00 pm and 16:00 pm In Egyptian Rahman i, Ossimi and OssimixSuffolk crossbred ewes. Similar trend was observed by Sejian et al. (2012) who found higher respiration rate in afternoon than morning in Malpura sheep of semiarid region.

\section{c) Pulse rate (PR, beat/ $\mathrm{min})$ :}

Pulse rate significantly $(p<0.01)$ affected by the season of the year (S), hours of the day (D) and the interaction of Sx D, however the effects of breed (B), interaction of SxB, BxD and SxBxD were not significant.

In this concern, the highest significant overall average of (PR) for males (87.80 beat/ min) of Damascus and Zarabi goats was recorded in summer season, followed by that recorded in autumn (8 5.8 beat $/ \mathrm{min})$, spring $(70.5 \mathrm{beat} / \mathrm{min}$ ) and the lowest one was in winter season $(68.8$ beat/ $\mathrm{min}$,). The differences among seasons were significant expect the differences of values recorded in winter and spring were not significant as shown in Table (3). It is well documented that pulse rate influenced by various factors such as, season, day timings, ambient temperature, humidity and exercise (Marai et al. 2007).

Across hours of the day, The obtained results (Table, 3) illustrate that the highest activity of pulse rate observed and recorded at 12:00 hrs (82.5 beat/ $\mathrm{min})$ as compared to that observed at 7:00 hrs ( $75.3 \mathrm{beat} / \mathrm{min}$ ) or at 19:00hrs ( $76.9 \mathrm{beat} /$ min) with significant differences $(p<0.01)$ among hours of the day.

Based on various research findings, pulse rate increases in high environmental temperatures as reported by Marai et al. (2007) and Phulia SK, (2010). These findings come into agreement with those of Facanha DAE, (2012) who concluded that the marked acceleration of the heart rate occurred during the hottest part of the day. However, Al-haidary (2004) reported that exposure to heat stress reduced $(P<0.01)$ the daily average of heart rate (115.7 and $85.8 \pm .11$ beat $/ \mathrm{min}$ for the control and heat stress animals, respectively)., and observed the mark reduction of heart rate occurred during the hottest part of the daily cycle (1200- $1700 \mathrm{~h}$ ).

Finally, as seen, the results arein the same parallel with each other, where it is clearly appears that pattern of seasonal and diurnal changes of measured thermo regulatory responses of ( $R T, R R$ and PR) of the experimental animals almost is in harmony with the change in environmental changes of recorded climatic circumstances at the region of the study, especially ambient temperature and calculated thermal humidity index (THI). 
Table (3): Seasonal and diurnal changes of Pulse rate (beat/min) of Damascus and Zarabi male goats

\begin{tabular}{|c|c|c|c|c|}
\hline \multirow{2}{*}{ Season (S) } & \multirow{2}{*}{$\begin{array}{l}\text { Time of day } \\
\text { (D) }\end{array}$} & \multicolumn{2}{|c|}{ Breed (B) } & \multirow{2}{*}{ Overall $(S \times D)$} \\
\hline & & Damascus & Zarabi & \\
\hline \multirow{3}{*}{ Winter } & $07.00 \mathrm{~h}$ & $66.7 \pm 1.3$ & $65.9 \pm 1.3$ & $66.3 \pm 0.8^{\mathrm{E}}$ \\
\hline & $12.00 \mathrm{~h}$ & $72.1 \pm 1.3$ & $72.3 \pm 1.3$ & $72.3 \pm 0.8^{D}$ \\
\hline & $19.00 \mathrm{~h}$ & $68.7 \pm 1.3$ & $66.9 \pm 1.3$ & $67.8 \pm 0.8^{\mathrm{E}}$ \\
\hline \multicolumn{2}{|r|}{ Overall (S x B) } & $69.2 \pm 0.7$ & $68.4 \pm 0.7$ & $68.8 \pm 0.5^{c}$ \\
\hline \multirow{3}{*}{ Spring } & $07.00 \mathrm{~h}$ & $67.6 \pm 1.3$ & $67.0 \pm 1.3$ & $67.3 \pm 0.8^{\mathrm{E}}$ \\
\hline & $12.00 \mathrm{~h}$ & $72.0 \pm 1.3$ & $72.1 \pm 1.3$ & $72.0 \pm 0.8^{D}$ \\
\hline & $19.00 \mathrm{~h}$ & $72.4 \pm 1.3$ & $72.2 \pm 1.3$ & $72.3 \pm 0.8^{D}$ \\
\hline \multicolumn{2}{|r|}{ Overall (S x B) } & $70.6 \pm 0.7$ & $70.4 \pm 0.7$ & $70.5 \pm 0.5^{c}$ \\
\hline \multirow{3}{*}{ Summer } & $07.00 \mathrm{~h}$ & $83.8 \pm 1.3$ & $83.0 \pm 1.3$ & $83.4 \pm 0.8 B^{C}$ \\
\hline & $12.00 \mathrm{~h}$ & $97.6 \pm 1.3$ & $91.2 \pm 1.3$ & $94.4 \pm 0.8^{A}$ \\
\hline & $19.00 \mathrm{~h}$ & $85.8 \pm 1.3$ & $85.4 \pm 1.3$ & $85.6 \pm 0.8^{B}$ \\
\hline \multicolumn{2}{|r|}{ Overall (S x B) } & $89.0 \pm 0.7$ & $86.6 \pm 0.7$ & $87.8 \pm 0.5^{A}$ \\
\hline \multirow{3}{*}{ Autumn } & $07.00 \mathrm{~h}$ & $83.6 \pm 1.3$ & $84.7 \pm 1.3$ & $84.1 \pm 0.8 B^{C}$ \\
\hline & $12.00 \mathrm{~h}$ & $91.1 \pm 1.3$ & $91.8 \pm 1.3$ & $91.4 \pm 0.8^{A}$ \\
\hline & $19.00 \mathrm{~h}$ & $80.8 \pm 1.3$ & $82.6 \pm 1.3$ & $81.7 \pm 0.8^{C}$ \\
\hline \multicolumn{2}{|r|}{ Overall (S x B) } & $85.15 \pm 0.7$ & $86.40 \pm 0.70$ & $85.8 \pm 0.5^{B}$ \\
\hline \multicolumn{2}{|r|}{ Total } & $78.5 \pm 0.2$ & $77.9 \pm 0.2$ & \\
\hline \multirow{2}{*}{\multicolumn{2}{|c|}{$\frac{\text { Overall (B x D) }}{07.00 \mathrm{~h}}$}} & & & \\
\hline & & $75.4 \pm 0.6$ & $75.8 \pm 0.6$ & $75.3 \pm 0.4^{c}$ \\
\hline & $12.00 \mathrm{~h}$ & $83.3 \pm 0.6$ & $81.8 \pm 0.6$ & $82.5 \pm 0.4^{A}$ \\
\hline & $19.00 \mathrm{~h}$ & $76.9 \pm 0.6$ & $76.8 \pm 0.6$ & $76.8 \pm 0.4^{B}$ \\
\hline
\end{tabular}

A, B : Values in the same column or row within certain trait with different super scripts are significantly differed $(P<0.05)$.

In the present study, results pointed out that the highest the overall averages of $R T$, RR and PR were recorded in summer season for males $(39.06,38.4$ and 87.8) as shown in Tables $(1,2$, and 3$)$ of Damascus and Zarabi goats were accompanied with the highest recorded ambient temperature and the highest calculated THI in summer season.

These observations are agreement with those of Yorulmaz (2014) who found that respiratory rate generally increased in parallel with the rise in temperature or $\mathrm{THI}$ in the summer, but recessed back to the lowest level in the winter, and to those of Ibrahim (2001) on camels. Moreover, (Alamer and Al-Hazah 2004) concluded that the respiratory rate followed the same pattern of variation as observed with rectal temperature, so, it is suggested that respiration rate and rectal temperature are ideal indicators for quantifying heat stress in several ruminant species (Chauhan et al., 2014). It could be concluded that the seasonal changes of the rectal temperature, respiratory rate and pulse rate are in harmony with the changes in environmental temperature. 
II. Seasonal variation in erythrocvtes indices and Leucocytes in males of Damascus and Zarabi goats:

a- RBCs indices:

Total count of erythrocytes, Leucocytes, Heamoglobin and packed cell volume (Table, 4) and for the erthrocytic indices including $\mathrm{MCV}, \mathrm{MCH}$, MCHC (Table, 5) in the blood samples obtained from males of Damascus and Zarabi goats were significantly $(p<0.01)$ affected by season of the year. These results agree with the findings of Tibbo et al. (2008) which stated that season affected almost all erythrocyte series in small ruminants. In contrast, Aengwanich et al. (2009) reported no significant effect of season on haematological values of crossbred beef cattle at slaughterhouse in northern part of Thailand. According to the available literature, there are several factors include season of the year (Oladele et al., 2005), animal breed (Tibbo et al., 2008a; Tibbo et al., 2008b), biological rhythms (Azeez et al., 2009), age (Olayemi and Nottidge, 2007; Devi and Kumar, 2012), sex (Gabriel et al., 2004; Cetin et al., 2009), pregnancy (Farooq et al., 2011; Okonkwo et al., 2011a), nutritional status (lyayi, 2001), affect hematological and biochemical profile.

The listed data indicate that the overall average of RBCs, amount of haemoglobin and PCV (ranged from 8.9 $11.8 \times 106 / \mu \mathrm{L} 0,8.1-9.6 \mathrm{~g} / \mathrm{dL}$, and $26.8-$ $30.4 \%$, respectively) in the blood of Damascus and Zarabi goats (Table, 4,5). The highest overall average of RBCs, $\mathrm{Hb}$, $\mathrm{PCV}$ and $\mathrm{MCHC}$ were recorded in winter season for blood samples obtained from males $(11.8 \times 106 / \mu \mathrm{L}, 9.4 \mathrm{~g} / \mathrm{dL}, 30.9 \%$ and $31.7 \mathrm{~g} / \mathrm{dl}$ )) of Damascus and Zarabi goats.

The present results of are in agreement with the findings of Holman and Dew (1966) in goats. However, abdelatif, A. et al., (2009) found the highest values of erythrocyte count, packed cell volume (PCV) and haemoglobin concentration $(\mathrm{Hb})$ were during wet summer and the lowest values were in dry summer in Nubian goats, the erythrocyte counts during winter and dry summer did not differ significantly, while the difference in (PCV) was not significant between wet summer and winter. These variations in responses of goats may be attributed to differences in environmental conditions as well as nutritional factors (Pospisil et al. 1987). The lowest values of RBCs were recorded $(p<0.01)$ in summer season for males $(9.1 \times 106 / \mu \mathrm{L})$ of Damascus and Zarabi goats, However, the lowest value of $\mathrm{Hb}$ and $\mathrm{PCV}$ were recorded in summer season $(8.2 \mathrm{~g} / \mathrm{dL}$ and $27.1 \%$, respectively)

The lowest values of RBCs, $\mathrm{Hb}$ and PCV were recorded in summer season $(9.1 \times 106 / \mu \mathrm{L}, 8.2 \mathrm{~g} / \mathrm{dL}$ and $27.1 \%$, respectively) for males of Damascus and Zarabi goats as shown in Tables (4 and 5). Abdelatif, A. et al., (2009) illustrated that the decline in erythrocyte count and consequently (PCV) and ( $\mathrm{Hb}$ ) could be related to depression of thyroid secretion which is associated with decreased erythropoiesis. A depression of thyroid hormone secretion during summer was reported in goats (Prakash, $p$ 1991) and sheep [Assane, $M$ and Sere, A 1990., and Okab, A et al., 1993).

As for indices of RBCs in the blood of the experimental animals, results show that the highest values of $\mathrm{MCV}$ and $\mathrm{MCH}$ were recorded in summer season in blood samples for males (30.4 fl, and 9.0 pg) of Damascus and Zarabi goats (Table, 6). Almost imilar observations noted by Kumar and Pachura, (2000) who reported that $\mathrm{MCV}, \mathrm{MCH}$ and $\mathrm{MCHC}$ were higher in summer, while PCV was lower during winter, conversely, Abdelatif et al. (2009) observed that MCV and $\mathrm{MCH}$ were significantly higher during winter than in either wet or dry summer in Nubian goats. 


\begin{tabular}{|c|c|c|c|c|c|c|}
\hline \multirow{3}{*}{$\begin{array}{l}\overline{2} \\
\overrightarrow{2}\end{array}$} & $\begin{array}{l}\text { 嵔 } \\
\text { 变 } \\
\end{array}$ & 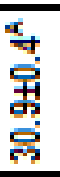 & $\begin{array}{l}\text { 吊 } \\
\text { 曽 } \\
\text { 总 }\end{array}$ & 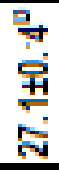 & 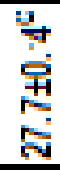 & \\
\hline & $\begin{array}{l}\text { 莺 } \\
\text { 焉 }\end{array}$ & 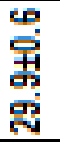 & 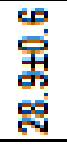 &  & 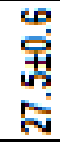 & $\begin{array}{l}\text { 吾 } \\
\text { मे }\end{array}$ \\
\hline & $\begin{array}{l}\text { 岑 } \\
\text { 岁 } \\
\text { 恶 } \\
\text { 总 }\end{array}$ & 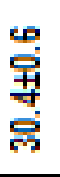 & 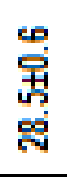 & $\begin{array}{l}\text { 总 } \\
\text { 晋 } \\
\text { 总 }\end{array}$ & $\begin{array}{l}\text { 号 } \\
\text { 吾 } \\
\text { s }\end{array}$ & 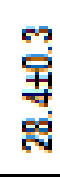 \\
\hline \multirow{3}{*}{$\begin{array}{l}\overrightarrow{\bar{D}} \\
\text { 믈 } \\
\text { 总 }\end{array}$} & 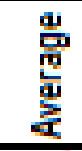 & 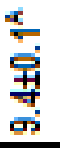 & 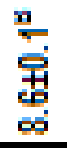 & 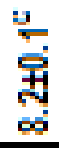 & $\begin{array}{l}\text { 是 } \\
\text { 总 } \\
\text { o }\end{array}$ & \\
\hline & $\begin{array}{l}\text { 莺 } \\
\text { 焉 }\end{array}$ & 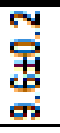 & 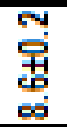 & 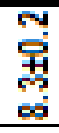 & $\begin{array}{l}5 \\
\text { 吾 } \\
\text { 吾 }\end{array}$ & $\begin{array}{l}5 \\
\text { 둔 } \\
\text { 형 }\end{array}$ \\
\hline & $\begin{array}{l}\text { 岁 } \\
\text { 㟔 } \\
\text { 兽 } \\
\text { 总 }\end{array}$ & $\begin{array}{l}\text { 总 } \\
\text { 足 }\end{array}$ & 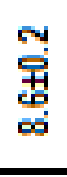 & 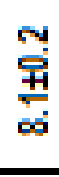 & $\begin{array}{l}\text { 畐 } \\
\text { D }\end{array}$ & $\begin{array}{l}\text { 독 } \\
\text { 恶 }\end{array}$ \\
\hline \multirow{3}{*}{ 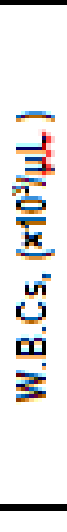 } & $\begin{array}{l}\text { 搃 } \\
\text { 变 } \\
\end{array}$ & 吾 &  & $\begin{array}{l}\text { 是 } \\
\text { 总 } \\
\text { 晋 }\end{array}$ & 를 & \\
\hline & $\begin{array}{l}\text { 莺 } \\
\text { 覀 }\end{array}$ & 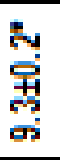 & 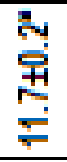 & 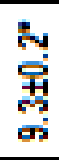 & 点 & 할 \\
\hline &  & 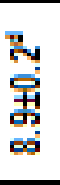 & 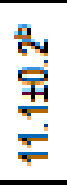 & 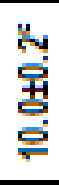 & 总 & 룰 \\
\hline \multirow{3}{*}{ 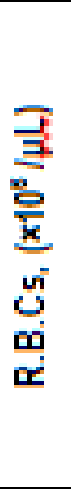 } &  & $\begin{array}{l}5 \\
9 \\
5 \\
5\end{array}$ &  & $\begin{array}{l}\text { 물 } \\
\text { 훌 } \\
\text { 함 }\end{array}$ & 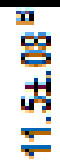 & \\
\hline & $\begin{array}{l}\text { 룜 } \\
\text { 墨 } \\
\end{array}$ & 要 & 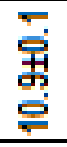 & 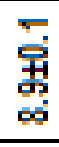 & 完 & $\begin{array}{l}\text { 릉 } \\
\text { 总 }\end{array}$ \\
\hline & $\begin{array}{l}\text { 岁 } \\
\text { 岁 } \\
\text { 兽 } \\
\text { 兽 } \\
\end{array}$ & 宔 & $\begin{array}{l}\text { 림 } \\
\text { 茄 }\end{array}$ & 韋 & 吾 & $\begin{array}{l}\text { 욜 } \\
\text { 률 }\end{array}$ \\
\hline \multicolumn{2}{|c|}{$\begin{array}{l}\text { 吕 } \\
\text { 总 }\end{array}$} & $\begin{array}{l}\text { 辛 } \\
\text { 를 }\end{array}$ & $\begin{array}{l}\text { 몰 } \\
\text { 蒠 } \\
\end{array}$ & 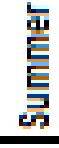 & \begin{tabular}{l} 
듵 \\
当 \\
\multirow{2}{*}{}
\end{tabular} & $\begin{array}{l}\mathrm{a} \\
\mathrm{T} \\
\stackrel{\mathrm{m}}{\mathrm{z}} \\
\end{array}$ \\
\hline
\end{tabular}


In addition the lowest values of MCV and $\mathrm{MCH}$ were observed in autumn (24.0 $\mathrm{fl}$ and $7.1 \mathrm{pg}$ ) for males of the experimental goats. While, the lowest values of $\mathrm{MCHC}$ were recorded $(30.3 \mathrm{~g} / \mathrm{dl})$ in spring and summer seasons as shown in Table (5). The low (MCV) value obtained could be related to the negative correlation between size and number of erythroytes [(Holman et al., 1964).

\section{b- Leucocytes (WBCs):}

The total count of Leucocytes in the blood samples obtained from males of Damascus and Zarabi goats was significantly $(p<0.01)$ affected by season of the year. However, Abdelatif et al. (2009) did not observe any significant effect of season on total count of Leucocytes.
Results in Table (4) revealed that the overall average number of WBCs in that blood samples ranged from 9.6 to 11.4 $\times 103 / \mu \mathrm{L}$ (Table, 4). The highest overall average of the total WBC was recorded in spring season $(11.4(\times 103 / \mu \mathrm{L})$, however, the lowest values of WBC were recorded in winter $(9.1 \times 103 / \mu \mathrm{L})$ in the blood samples obtained from males of Damascus and Zarabi goats. Abdelatif et al. (2009) indicated that the total count of Leucocytes showed apparently limited fluctuations ranging between $9.00 \mathrm{x}$ $103 / \mu \mathrm{L}$ in dry summer and $11.93 \times 103 / \mu \mathrm{L}$ in winter. Similarly, other workers (Vaidya, M.B. 1970 and Vegula, I. 1985) did not report significant effect of season on total count of Leucocytes in goats.

Table (5): Seasonal variation of Mean corpuscular volume (MCV), Mean corpuscular Hemoglobin (MCH), Mean corpuscular Hemoglobin concentration (MCHC) in males of Damascus and Baladi goats:

\begin{tabular}{|c|c|c|c|c|c|c|c|c|c|}
\hline \multirow{2}{*}{ Season } & \multicolumn{3}{|c|}{$\operatorname{MCV}(f l)$} & \multicolumn{3}{|c|}{$\mathrm{MCH}(\mathrm{pg})$} & \multicolumn{3}{|c|}{$\mathrm{MCHC}(\mathrm{g} / \mathrm{dl})$} \\
\hline & Damascus & Baladi & Average & Damascus & Baladi & Average & Damascus & Baladi & Average \\
\hline Winter & $25.4 \pm 0.4$ & $25.8 \pm 0$ & $25.6 \pm 0.3^{B}$ & $7.9 \pm 0.1$ & $8.2 \pm 0.1$ & $8.0 \pm 0.1^{B}$ & $31.3 \pm 0.2$ & $32.1 \pm 0.2$ & $31.7 \pm 0.1^{A}$ \\
\hline Spring & $25.5 \pm 0.4$ & $26.2 \pm 0.4$ & $25.8 \pm 0.3^{B}$ & $7.7 \pm 0.1$ & $7.9 \pm 0.1$ & $7.8 \pm 0.1^{B}$ & $30.3 \pm 0.2$ & $30.3 \pm 0.2$ & $30.3 \pm 0.1^{B}$ \\
\hline Summer & $30.8 \pm 0.4$ & $30.1 \pm 0$ & $30.4 \pm 0.3^{A}$ & $8.9 \pm 0.1$ & $9.2 \pm 0.1$ & $9.0 \pm 0.1^{A}$ & $30.3 \pm 0.2$ & $30.3 \pm 0.2$ & $30.3 \pm 0.1^{B}$ \\
\hline Autumn & $23.8 \pm 0.4$ & $24.3 \pm 0.4$ & $24.0 \pm 0.3^{c}$ & $7.1 \pm 0.1$ & $7.2 \pm 0.1$ & $7.1 \pm 0.1^{c}$ & $30.1 \pm 0.2$ & $30.9 \pm 0.2$ & $30.5 \pm 0.1^{c}$ \\
\hline Average & $26.4 \pm 0.2$ & $26.6 \pm 0.2$ & & $7.9 \pm .08^{B}$ & $8.1 \pm .08^{A}$ & & $30.5 \pm 0.1^{B}$ & $30.9 \pm 0.1^{A}$ & \\
\hline
\end{tabular}

A, B, C = Values in the same column or row within certain trait with different super scripts are significantly differed $(P<0.05)$. 


\section{REFERENCES}

Abdelatif, A.M., Y.M. Ibrahim and M.Y. Hassan (2009). Seasonal variation in erythrocyte and leukocyte indices and serum proteins of female Nubian goats. Middle-East. J. Sci. Res. 4(3): 168 - 174.

Abi-Saabad S. and Saleim F.T. (1995). Physiological responses of stress of filial crosses comparedto local Awassi sheep. Small Rumin. Res. 16: 55-59.

Aengwanich W, Chantritratikul A, Pamok S. (2009). Effect of seasonal variations on haematological values and health monitor of crossbreed cattle at slaughterhouse in Northern eastern part of Thailand. American-Eurasian $\mathrm{J}$. Agric. Environ. Sci. 5 (5): 644-648.

Akinrinmade, J. F. and A. S. Akinrinde (2012). Haematological and Serum biochemical indices of West Africandwarf goats with foreign body rumenimpactation. Nigerian Journal of Physiological Sciences, 27: 083 - 087.

Alamer, A. and Al-Hazah, A. (2004). Effect of Water Deprivation and Season of Feed Intake, Body Weight and Thermoregulation in Awassi and Najdi Sheep Breeds in Saudi Arabia. Journal of Arid Environments, 59,7184. http://dx.doi.org/10.1016/j.jaridenv.200 4.01.003.

Al-haidary, AA. (2004). Physiological Responses of Naimey Sheep to Heat Stress Challenge under Semi-Arid Environments. Int J Agr Biol. 6:15608530./2004/06-2-307-309.

Appleman, R.O. and J.C. Delouché (1958). Behavioural, physiological and biochemical responses of goats to Temperature, $0^{\circ}$ to $40^{\circ} \mathrm{C}$ J. Animal Sci., 17: 326-335.

Assane, M. and A. Sere. (1990). Influence of season and gestation on plasma concentration of thyroid hormones: triiodothyronine (T3 ) and thyroxine (T4 ) in Peuth ewes of the Sahel. Annals de Recherches Veterinaires, 21: 285-289.
Azeez, O.I., A.A. Oyagbemi, J.O. Oyewale (2009). Diurnal fluctuation in haematological parameters of the domestic fowls in the hot humid tropics. Int. J. Poult. Sci. 8(3): 247-251

Bligh J. Temperature regulation (1985). In: Stress physiology inlivestock. Basic Principles, Yousef M.K. (ed.). CRC Press Inc., Boca Raton, FL, USA.; 1:75-96.

Bohmanova, J., I. Misztal and J.B. Cole (2007). Temperature-humidity indices as indicators of milk production losses due to heat stress. J Dairy Sci 90:1947-1956

Ceyhan, A., C. Kaptan, M. Ada, İ Erdoğan and AM. Taluğ (2006). The Physiological Reactions in Bandrma Environment Conditions of Kıvırcık, German Black headed Mutton, (GBH x Kivircik) F1 and (GBH xF1) B1 Ewe. A. Ü. Ziraat Fak. Tarım Bilimleri Derg.12, P. 113-120 (in Turkish).

Chauhan, S. S., P. Celi, B. J. Leury, I. J. Clarke and F. R. Dunshea (2014). Dietary antioxidants at supranutritional doses improve oxidative status and reduce the negative effects of heat stress in sheep. J. Anim. Sci . 92:3364-3374.

Crosby, W. H., J. I. Munn and F. W. Furth (1954). Standardizing method for clinical hemoglobinometry. United States Armed Forces. Medical Journal, 5: 693- 703.

Devi, R. and M.P. Kumar (2012). Effect of ageing and sex on the ceruloplasmin (Cp) and the plasma protein levels. J. Clini. Diagn. Res. 6(4): 577-580.

Facanha, D.A.E., L. Sammichelli, R. Bozzi, W.S.T. Silva, J.H.G. Morais and R.M.O. Lucena (2012a). Performance of Brazilian native goats submitted to a mix supply underthermal stress conditions. Proc. XI International Conference on Goats, Gran Canaria, Spain. 343.

Fahmy, S. (1994). Effect of crossing Romanov with Rahmani sheep on some physiological and productive 
performance. M.Sc. thesis. Faculty of Agriculture, AIAzhar University, Cairo, Egypt.

Farooq, H., H.A. Samad and S. Sajjad (2011). Normal reference Haematological values of one-humped camels (Camelus Dromedarius) kept in Cholistan desert. J. Anim. Plant Sci. 21(2): 157-160.

Galal S., Abdel Rasoul F., Anous M.R., Shaat I. (2005). Small ruminant breeds

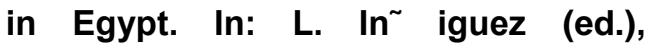
Characterization of Small Ruminant Breeds in West Asia and North Africa Vol. 2. North Africa. International Center for Agricultural Research in the Dry Land (ICARDA), Aleppo, Syria, pp. 140-193.

Habeeb, A. A. M., A. M. Abdel-Samee, E. S. ELGohary and A. E. Gad (2010a). Improving the growth performance of heat stressed lambs using treated rice straw of diet with effective microorganisms. Zag. Vet. J., 38(1): 112.

Hepler. O.E. (1966). Manual of the Clinical Laboratory Methods. Thomas, Springfield, Illioni, USA.

Holman, H.H. and S.M. Dew (1964). The blood picture of the goat. II. Changes in erythrocytc shape, size and number associated with age. Research in Veterinary Sci., 5: 274-285.

lyayi, E.A. (2001). Cassava leaves as supplements for feeding weaner swine. Trop. Anim. Prod. Invest. 4: 141-150.

Kayabasi, D. (2011). Studies On the physiological responses related to seasonal variation in çukurova saanen and balcali goats under sub-tropical climate conditions. ÇÜ Fen ve Mühendislik Bilimleri Dergisi Yıl: 2012 Cilt: 28-1.

Kolmer, J. A., E. H. Spaulding and H. W. Robinson (1951). Approved Laboratory Techniques. (5 ${ }^{\text {th }}$ Edition). Appleton Century Crofts. Inc, New York. 118 pp.
Kumar, B. and SP. Pauchaura (2000). Haematological profile of crossbred dairy cattle to monitor herd health status at medium elevation in central Himalayas. Res. Vet. Sci. 69: 141-145.

Mader, T. L., M. S. Davis and T. BrownBrandl (2006). Environmental factors influencing heat stress in feedlot cattle. J. Anim. Sci., 84:712-719.

Marai, I.F.M. and A.A.M. Habeeb (2010). Buffalo's biological functions as affected by heatstress-A review. Journal of Livestock Science,127, 89109.

Marai, I.F.M., A.A. El-Darawany, A. Fadiel and M.A.M. Abdel-Hafez (2007). Physiological Traits as Affected by Heat Stress in Sheep: A Review. Small Ruminant Research, 71, 1-12.

Marai, I.F.M., A. A. M. Habeeb, A.H. Daader and H.M. Yousef (1997). Effects of diet supplementation and body cooling on heat stressed Friesian calves reared in high ambient temperatures in the eastern desert of Egypt. Tropical Animal \& Health Production, 4:201-208.

McDowell, R.E., N.W. Hooven and J.K. Camoens (1976). Effect of climate on performance of Holsteins in first lactation. Journal of Dairy Science. 1976; 59: 965-973. doi: 10.3168/jds. S0022-0302(76)84305-6

Neves, M.L.M.W., M. Azevedo and L.A.B. Costa (2009). Níveis críticos do índice de conforto térmico para ovinos da raça Santa Inês criados a pasto no agreste do Estado de Pernambuco. Acta Scientarium. Animal Sciences, v.31, n.2, p.169-175

Nigm, A.A., R.R. Sadek, Sherien A. Yassien, M.A.M. Ibrahim and M. A. EIWardani (2015). Effect of climate change on test-day milk yield of Holstein cows maintained in the Nile Delta of Egypt. Egyptian J. Anim. Prod., 52(2):113-121

NRC. (2007). Nutrient requirements of small ruminants, sheep,goats, cervids, 
and new world camelids. NationalAcademy Press, Washington, DC.

Okab, A.B., I.M. El-Banna, M.Y., Mekkawi, F.D. El-Nouty and M.H. Salem (1993). Seasonal changes in plasma thyroid hormones, total lipids and serum transaminases during pregnancy and at parturition in Barki and Rahmani ewes. Indian Journal of Animal Sci., 63: 946-951.

Olayemi, F.O. and H.O. Nottidge (2007). Effect of age on the blood profiles of the New Zealand rabbit in Nigeria. Afr. J. Biomed. Res. 10: 73 - 76.

Olayemi, F.O. and H.O. Nottidge (2007). Effect of age on the blood profiles of the New Zealand rabbit in Nigeria. Afr. J. Biomed. Res. 10: 73 - 76.

Phulia, S.K., R.C. Upadhyay, S.K. Jindal and RP. Misra (2010). Alteration in surface body temperature and physiological responses in Sirohi goats during day time in summer season. Indian Journal of Animal Science. 80(4):340-342.

Pospisil, J., F. Kase and J. Vahala (1987). Basic haematological values in the Cameroon goat (Capra hircus). Comparative Biochemistry and Physiology, 88A: 451-545.

Prakash, P. and V.S. Rathore (1991). Seasonal variations in blood serum profiles of triiodothyronine and thyroxine in goat. Indian Journal of Animal Sciences 61: 1311-12.

Prasetyo, S., H.M. Miller, E.A. Scheurman and J.H.G. Holmes (1984). The effect of heat and humidity on pregnant feral goats. Animal Production, 15: 41- 544.

Sanusi, A.O., S.O. Peter, A.O. Sonibare and M.O. Ozojie (2010). Effects of coat colour on heat stress among West African dwarf sheep. Nig. J. Anim. Prod., 38(1): 28-36.

SAS Institute. (2007). SAS/STAT® 9.2 . User's Guide. SAS Institute Inc., Cary, NC
Sejian, V., V.P. Maurya, K. Kumar and S.M.K. Naqvi (2012). Effect of multiple stresses on growth and adaptive capability of Malpura ewes under semi-arid tropical environment. Trop Anim Health Prod. 45(1): 107-16

Sejian, V., V. P. Maurya, K. Kumar and S. M. K. Naqvi (2013). Effect of multiple stresses (thermal, nutritional, and walking stress) on growth, physiological response, blood biochemical and endocrine responses in Malpura ewes under semi-arid tropical environment. Trop. Anim. Health Prod. 45:107-116. doi:10.1007/s11250-012-0180-7

Shalaby, T.H. (1985). Performance and adaptation of local sheep to varied environmental and managerial conditions. Ph.D. thesis. Faculty of Agriculture, Cairo University, Cairo, Egypt.

Sherien, A. Yassien (2016). Effect of climate change on milk production of Holstein cows maintained in the Nile Delta of Egypt. Ph.d Thesis. Faculty of Agriculture, Animal Production department, Cairo university, Egypt.

Smith, M., and D. Sherman (2009). Goat Medicine, 2nd ed Ames, lowa: WileyBlackwell.

Srikandakumar, A., E.G. Johnson and O. Mahgoub (2003). Effect of heat stress on respiratory rate, rectal temperature and blood chemistry in Omani and Australian Merinosheep. Small Ruminant Research. 49, P. 193-198.

Soryal K.A., Metawi H.R. (2000). Future prospects of goats as a source of milk to decrease the milk gap in Egypt. Two potential advantages of dairy goats. Proceedings of the International Symposium, Prospects for a Sustainable Dairy Sector in the Mediterranean. Hammamet, Tunisia, Oct. 26-28, pp. 337-343.

Tibbo, M., Y. Jibril, M. Woldemeskel, F. Dawo, K. Argaw, J.E.O. Rege (2008a). Serum enzyme levels and influencing factors in three indigenous Ethiopian 
goats breeds. Trop. Animl. Health Prod. 40: 657-666.

Tibbo, M, M. Woldemeskel, K. Argaw and J.E.O. Rege (2008b). Serum enzymelevels and influencing factors in three indigenous Ethiopian sheep breeds. Comp. Clin. Pathol. 17 (3): 149-155.

Vaidya, M.B., P.M. Vaghari and B.M. Patel. (1970). Haematological constituents of blood of goats. Indian Veterinary Journal, 47(8): 642-647.

Vergula, L., H. Seidel and J. Garadas. (1985). Yearly dynamics of haematological and biochemical indices in the blood and blood serum of goats. Folia Veterinaria., 29: 3-69.
West, J.W. (1999). Nutritional strategies for managing the heatstressed dairy cow. J Anim. Sci. 77:21-35.

Yousef, HM. (1985). Studies on some environmental factors affecting production and reproduction in some farm animals. MSc Thesis, Faculty of Agriculture, Zagazig University, Zagazig.

Yorulmaz, E. (2014). The seasonal change of some physiological stress parameters in sheep. Adnan Menderes university Agriculture Faculty Department of Animal Science: (Master's thesis), Aydın (in Turkish). 
تأثير الموسم على بعض قياسات الدم ومؤشرات التظيم الحرارية في الماعز الامشقي والزرايبى

حلمى عبدالرحمن عبدالهادى، ريم صابر مراد، مرفت مختار سليمان، عبدالله فتحى نيير قسم الإنتاج الحيوانى - كلية الززاعة - جامعة المنوفية هين

الملغص العربى

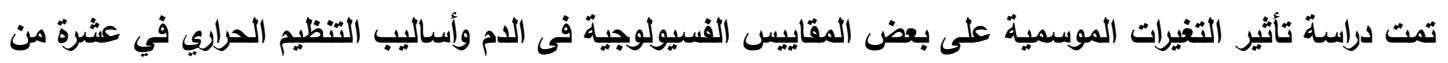

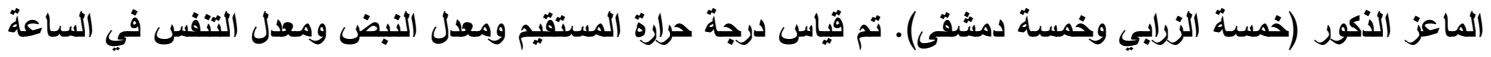

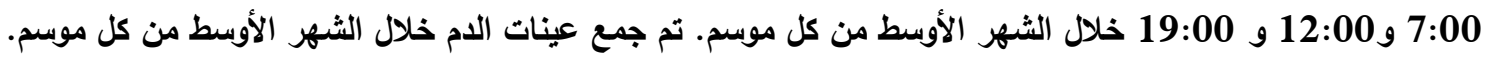

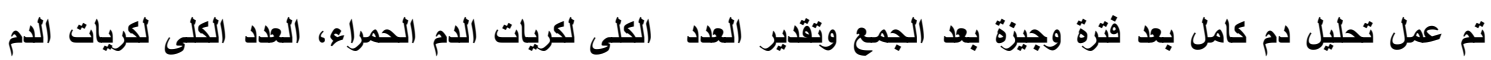

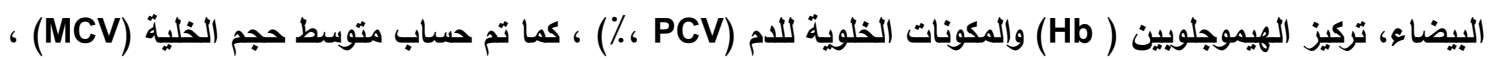

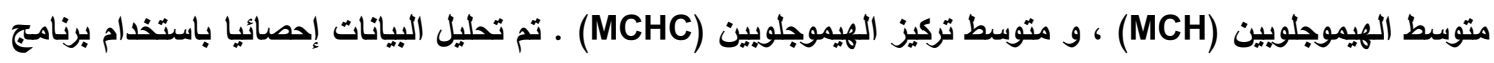

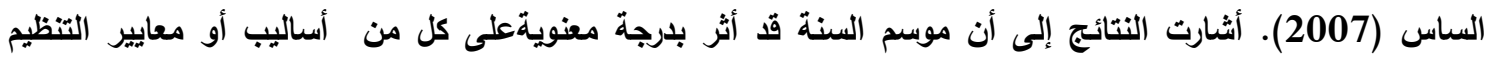





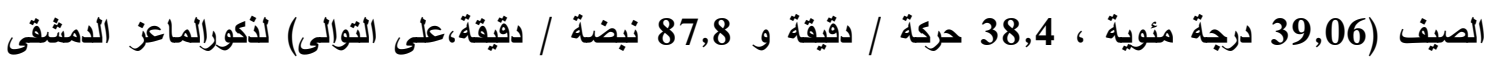

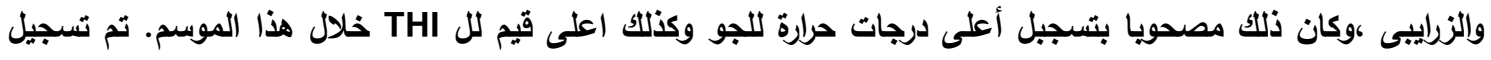

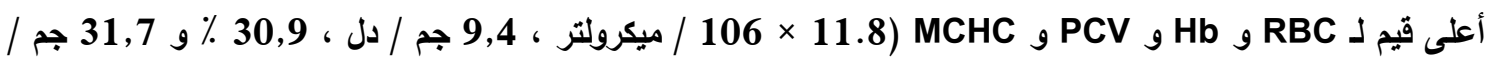
دل)) في فصل الثتاء ، وأعلى قيم لـ MCV

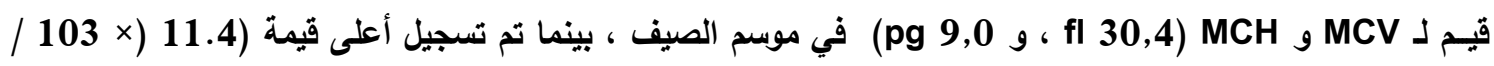

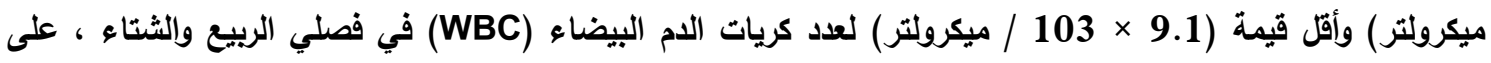

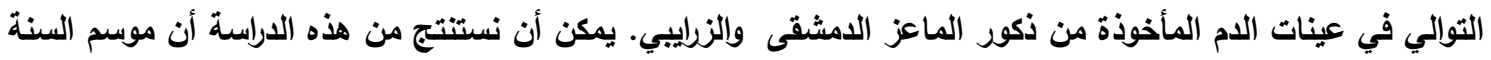

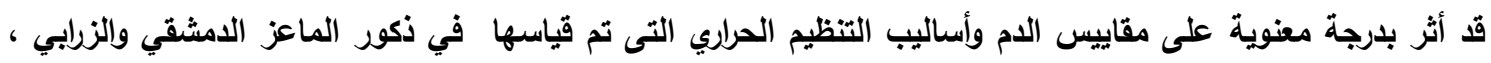

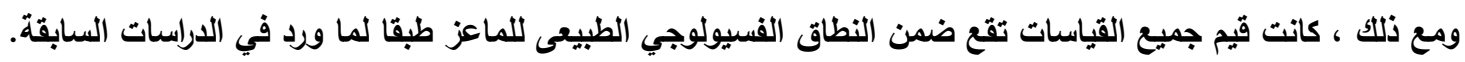


Menoufia J. Animal, Poultry \& Fish Prod., Vol. 3 December (2019): 137 - 151 